10.2478/cer-2013-0004

\title{
BEATA GUZIEJEWSKA*
}

\section{An Assessment of the Implementation of Performance Budgeting in Poland with Reference to the Experiences of Other Countries}

\begin{abstract}
Since the last global financial crisis, public expenditures have been experiencing increasing budget constraints. Therefore, public authorities search for solutions that would foster efficient and transparent expenditures at both the national and local government levels. One of the tools at their disposal is the performance-based budget, which is not, however, cheap or easy to implement. The aim of this paper is an assessment of the implementation of performance budgeting in Poland, and a formulation of proposals de lege ferenda. The assessment discusses selected aspects and conclusions which emerge from the experiences of other countries. The main thesis, set forth in the conclusion of this article, is that in many countries, including Poland, the implementation of a performance-based budget takes place at the national level, not at the local government level, which seems to be questionable, or even incorrect.
\end{abstract}

\section{Introduction}

The financial crisis, which unfolded in 2008, has brought about not only a redefinition of fiscal policy in the EU countries on the macroeconomic scale (European Commission 2009), but also a new approach to the structure and efficiency of budget expenditures. Performance budgeting (also referred to as

${ }^{*}$ Ph.D., Professor at the University of Łódź, Faculty of Economics and Sociology, Public Finance Chair 
performance-based budgeting in the literature) is one of the many tools available to improve the efficiency of public expenditures (Coombs, Jenkins 1994), and of the so-called New Public Management. However, this tool is complex from both the methodological and practical implementation points of view (Young R.D. 2003, pp. 2-3). As has been underlined in an OECD report, "There is no one model of performance budgeting; countries need to adapt their approach to the relevant political and institutional context" (OECD 2007, p.12). Nevertheless, since the very beginning of its transformation Poland has drawn from types of solutions and experiences of other countries, and this is equally true in the area of performance budgeting and long-term fiscal planning. The countries that are most frequently quoted in this context include the USA, the UK, New Zealand, France, Norway and Slovakia.

Despite the unquestionable need for efficient and rational management in the public sector, performance budgeting raises doubt and controversy in Poland and the public finance decision-makers either misunderstand it or have reservations about it. In my opinion, it was a gross mistake not to clearly outline the nature of the budgeting as strategic or operational. Like many other countries, Poland laid the legal foundations for performance budgeting at the national level, excluding the territorial self-government level and the National Health Fund. Performance budgeting is, however, first of all a tool of an operational character, which is determined by the specific character of individual tasks at different tiers of public government and the measures and means available for funding these tasks.

The aim of this paper is an assessment of the implementation of performance budgeting in Poland and formulation of proposals de lege ferenda. The assessment also relies on selected aspects and conclusions that emerge from the experiences of other countries.

\section{The nature and importance of performance budgeting}

Performance budgeting means moving away from expenditure in favour of financial means management. In the OECD approach, performance budgeting links the funds allocated to the results and adequacy of measures undertaken (OECD 2005a). There is also a disputable, in my view, approach where the role of performance budgeting is seen in the context of efficient management of governmental public institutions and strategic policy at the national level (Hardt, Maarten de Jong 2011, p.6). 
In Poland, performance-based budgets were pioneered by large cities in the 1990s. At the national level, the government proposed a budget with a dual approach in 2008. Apart from the traditional budget based on the budgetary classification sections, a performance-based budget was also presented. The implementation of the performance-based budget was devised as an undertaking that would last for many years and would be financed by EU funds. At present, the schedule covers the years 2009-2015 and improvements to the methodology and implementation of the performance-based budget are among the main objectives of the Department for Public Finance Reform, which was set up in the Ministry of Finance. It has been assumed that, thanks to better identification of state tasks, the performance-based budget should enhance the transparency of public expenditures and their efficiency and rationality. Indirectly, it should also contribute to a better coordination of targets and coherency of economic policy. Moreover, inasmuch as it ascribes priorities to the targets pursued by the government, the performance-based budget facilitates multi-annual planning of state expenditures. All of this, however, depends on the specific circumstances surrounding particular expenditures, and the many conditions that must be met. It is necessary, for example, to differentiate between the short-term and longterm tasks.

The team led by T. Lubińska concisely and rightly defined the essence of the performance-based budget as the management of public expenditures by means of concrete, hierarchical targets in order to reach the planned objectives, assessed by measurement tools adequate to specific tasks (Performance Budgeting Report 2007, p. 8). Therefore, at the outset of the implementation of performance budgeting, three fundamental elements essential to performance budgeting were outlined. These were tasks, results, and measures. According to the report, the three pillars of the performance-based budget include:

- implementation of specific tasks, which leads to an approach where the budget is not treated as an abstract plan of revenues and expenditures, but as a plan of expenditures which are directed towards the financing of specifically categorized tasks and public targets in accordance with the priorities defined by the state;

- definition of specific results and outcomes to be attained by the expenditure of public resources;

- devising measurement indicators which are used in performance analysis and the evaluation of task implementation by those persons or entities that are responsible for said implementation.

Looking at the revenue and expenditure sides of the traditional budget, it is difficult to obtain information on what specific services or public tasks are financed, what their hierarchy, duration and level of implementation are, and 
what entity is responsible for overseeing the process. The performance-based budget provides answers to several basic, highly important questions. The basic problem is what the scope of the tasks consists of, and what resources are allocated to these tasks. What objectives and results should be achieved? The traditional budget procedures are characterized by the lack of a direct link between public expenditures, tasks and, most importantly, their outcomes. Taking into consideration the economic criteria, this is a serious flaw of traditional budgeting. In performance budgeting, however, the use of specific measures for public tasks is indispensable. For every budget holder, tasks, subtasks, and actions (in the operational mode), together with objectives to be attained as a result of the tasks, and finally an indicator which consists of its name and value (base value, and value planned for a given year) must be established.

In performance budgeting, the key role is played by the economic indicators, which refer to efficiency and effectiveness (Lubińska ed. 2009, p.56). Efficiency indicators measure the progress towards the set objectives, whereas effectiveness indicators measure the relations between the input and the achieved outcome/result. This stress on efficiency and effectiveness results in the necessity to construct additional indicators which would be directly related to a given function, task, or sub-task. Constructing new indicators is both difficult and time-consuming. The formulation and choice of indicators that would be adequate to specific tasks, sub-tasks and functions of public institutions requires expertise and experience. It is advisable in the public sector to cautiously analyze and assess the relation between the level of allocated resources, the progress towards the objectives, and the implementation of public functions.

A measurable assessment of the performance of public tasks performance is not easy and cannot be done with the use of only one, synthetic measure (Lubińska ed. 2011, p. 209). Especially in the public sector, it is advisable to simultaneously analyze several indicators that describe the function and measure the effects of a given task, and that take into consideration its specific character. The so-called pilot programme revealed some of these problems. In the second half of 2006, work on the performance budget entered into the operational phase. It was decided to pioneer the first model of the state performance-based budget on the basis of the prepared methodology in two budgetary sections: Science and Higher Education (State Budget Implementation Report 2008). The practice of drafting a performance plan of expenditures by all the budget holders was established by an amendment to the Public Finance Act in December 2006 (Article 124, point 9 of the Public Finance Act of 2005). The same amendment stipulated that, beginning in 2008, the Council of Ministers should inform the 
Parliament on task implementation as part of the State Budget Implementation Report. It was concluded at the time that the drafting of a pilot assessment for the field of Science and Higher Education would play an important role in the state's performance budget experience and methodology before the obligatory drafting of information on the implementation of performance budgeting for the budget holders in the State Budget Implementation Report for 2008. The report, prepared by the Ministry of Science and Higher Education, was treated as a starting point and a contribution to the debate on further improvement of the methodology and facilitation of the implementation of performance-based budgeting in Poland. In the Ministry's opinion, it was the construction of the indicators that proved to be the most difficult, as the field of the pilot programme was considered to be one of the most difficult for performance budgeting due to its specific objectives and the immeasurability of effects.

The measuring of effects of public tasks in order to establish the relation of input to output is not easy in the public sector, and it encounters a number of obstacles in the administration itself. W. Misiag (2005, p. 153) underscores that "the demand to study the relations between the incurred public expenditures and their effects is not yet widely accepted." Among the numerous barriers to performance-based budgets in Poland, alongside the reluctance shown by administrative officials, one may enumerate inadequate legal regulations, lack of necessary statistical data systems, lack of highly trained apolitical officers, and the existence of administrative structures that are inadequate for management of the objectives, as has already been mentioned (Misiag 2007, p. 384). Some of these barriers have been removed in recent years. In Polish conditions, four principles have been set up as pillars of efficient management for performance budgeting: the principle of transparency, the principle of efficiency, the principle of multi-annual planning and the principle of consolidation of public expenditures.

Due to the complexity of performance budgeting and the practical problems associated with its implementation, the experiences of other countries are worthy of close analysis.

\section{Experiences of selected countries}

The experiences of individual countries in terms of the specific effects of performance budgeting are varied and ambiguous. Definitely there is no single, universal or agreed-upon optimal model of performance budgeting. This is due to the fact that different countries operate with different structures of public finance and different budgetary regulations. The implementation of 
performance-based budgets has usually been necessitated by public finance reforms, the introduction of multi-year budget planning, and/or the rationalization and reduction of public expenditures. The implementation of performance-based budgets is a multi-annual enterprise and the results of performance budgeting do not appear quickly or in a spectacular fashion.

Due to the wide variety of performance budgeting models, the OECD distinguishes three categories of performance budgeting based on the uses of performance information (performance measures and evaluations). Table 1 presents three categories of performance budgeting: presentational, performance-informed budgeting, and direct/formula performance budgeting.

Table 1. Performance budgeting categories.

\begin{tabular}{|llll|}
\hline Type & $\begin{array}{l}\text { Linkage between } \\
\text { performance } \\
\text { information and } \\
\text { funding }\end{array}$ & $\begin{array}{l}\text { Planned or actual } \\
\text { performance }\end{array}$ & $\begin{array}{l}\text { Main purpose in the } \\
\text { budget process }\end{array}$ \\
\hline Presentational & No link & $\begin{array}{l}\text { Performance targets } \\
\text { and/or performance } \\
\text { results }\end{array}$ & Accountability \\
\hline $\begin{array}{l}\text { Performance- } \\
\text { informed budgeting }\end{array}$ & Loose/indirect link & $\begin{array}{l}\text { Performance targets } \\
\text { and/or performance } \\
\text { results }\end{array}$ & $\begin{array}{l}\text { Planning and/or } \\
\text { accountability }\end{array}$ \\
\hline $\begin{array}{l}\text { Direct/formula } \\
\text { performance } \\
\text { budgeting }\end{array}$ & Tight/direct link & Performance results & $\begin{array}{l}\text { Resource allocation } \\
\text { and accountability }\end{array}$ \\
\hline
\end{tabular}

Source: Performance budgeting in OECD countries (2007), Paris, p. 21.

The first two models presented are the most frequently implemented types of performance budgeting, as the third model is based on too tight links between the information on the effectiveness of actions and their funding. The funding of public services and tasks directly in relation to the achieved results would lead to underfunding or disturbances in the financing of important social areas and unreliable budget accountability. Too much and too complex information is undesirable in performance budgeting. The biggest challenge in the development of a basic model of performance-based budgeting is keeping the performance information simple, affordable, and useable, (Robinson, Last 2009, p. 4). According to some researchers, an assessment of a given budgeting method can be carried out only in the context of its objectives and the wider context of reforms (Reddick 2003, pp. 315-340, Jordan, Hackbart 2005, pp. 471-487).

The reports of over $40 \%$ of OECD countries state that the first initiatives to measure the effects of the public sector expenditures appeared more than 15 years ago. The use of performance budgeting is a common trend nowadays, with nearly three-fourths of OECD countries including non-financial performance data in their budget documents. However, as has been mentioned earlier, the 
methodology, the scope and reasons for reforms of task-based budgeting vary in different countries. Table 2 shows the reasons for recent reforms in selected countries.

Table 2. Summary of some recently implemented reforms

\begin{tabular}{|l|l|l|l|}
\hline & Year & Reform & Purpose \\
\hline Australia & 2006 & $\begin{array}{l}\text { Revision of } \\
\text { expenditure review } \\
\text { methods }\end{array}$ & $\begin{array}{l}\text { To give a greater role to } \\
\text { the Ministry of Finance in } \\
\text { identifying and managing } \\
\text { reviews }\end{array}$ \\
\hline Canada & 2005 & $\begin{array}{l}\text { Management, } \\
\text { Resources, and } \\
\text { Results structure }\end{array}$ & $\begin{array}{l}\text { To set strategic outcomes } \\
\text { for all entities and to link } \\
\text { resources, performance } \\
\text { measures and actual } \\
\text { results for all programmes } \\
\text { (with ongoing } \\
\text { implementation) }\end{array}$ \\
\hline Denmark & $2004-2007$ & $\begin{array}{l}\text { Accrual accounting } \\
\text { and budgeting }\end{array}$ & $\begin{array}{l}\text { To implement accrual } \\
\text { accounting and budgeting } \\
\text { in the central government } \\
\text { sector }\end{array}$ \\
\hline Korea & 2006 & $\begin{array}{l}\text { Do develop strategic plans } \\
\text { that will be updated every } \\
\text { three years }\end{array}$ \\
\hline Netherlands & 2001 & $\begin{array}{l}\text { Policy-oriented form } \\
\text { of programme } \\
\text { budgeting }\end{array}$ & $\begin{array}{l}\text { To provide parliament } \\
\text { with a more transparent } \\
\text { budget document }\end{array}$ \\
\hline Swedget bill & $\begin{array}{l}\text { To link policy objectives } \\
\text { to expenditures }\end{array}$ \\
\hline United Kingdom & $2000,2002,2004$ & $\begin{array}{l}\text { Comprehensive } \\
\text { spending reviews and } \\
\text { public service } \\
\text { agreement }\end{array}$ & $\begin{array}{l}\text { To help allocate funding } \\
\text { to key priorities and to } \\
\text { help departments plan } \\
\text { ahead }\end{array}$ \\
\hline & 2002 & $\begin{array}{l}\text { To help assess how } \\
\text { programmes are } \\
\text { performing }\end{array}$ \\
\hline
\end{tabular}

Source: Performance budgeting in OECD countries (2007), Paris, p. 26.

Among the countries of Central and Eastern Europe, Slovakia, the Czech Republic, and Lithuania have some experience in performance budgeting. What is interesting is the fact that in these countries the performance-based budget has been extended to the parliaments as well. Thanks to the visit of the representatives of the Polish Ministry of Finance to Bratislava, the experiences of Slovakia have been relatively well-described in Poland [Ministry of Finance, 2009, pp. 5-9]. With support from the World Bank and American and Dutch experts, the debate on the new approach to public finance was launched in Slovakia in 2000. In 2002 a reform to the budget system was initiated as one of the indispensable components for improvement in the public finance system and 
the introduction of the common European currency. The reform introduced multi-year planning and a central system of budget management, which took over the managing functions from the National Bank of Slovakia. Also a programme-based budget as a data base for the performance-based budget was drafted. The programme-based budget was gradually extended to different ministries and budget holders. This programme-based budgeting is grounded on planning specific tasks and actions, which are defined by the strategic priorities outlined by the government. Its structure consists of programmes, subprogrammes, projects, and tasks. The methodology of programme-based budgeting also includes two types of programmes - programmes with a time frame and programmes without a specific time frame. The time frame programmes include specified dates when they commence and conclude, and defined targets and indicators, which undergo assessment throughout the period of implementation. Judging from the Slovakian experience, it seems that IT tools are of major importance. Upon commission by the Ministry of Finance, one of the companies produced an information system which provided high functionality across the hierarchy of budget institutions. The Slovakian experience also proved the usefulness of modern forms of budgeting in improving transparency and increasing the efficiency of public expenditures. The drawbacks that were revealed were similar to the difficulties faced by other countries. Problems emerged with the defining of objectives and especially the indicators designed to measure their implementation. The indicators often fail to concretely measure the effectiveness of individual expenditures, and the link between the expenditures and the objectives is not always clear. Performance budgeting, and its specific character, were also often unsupported or misunderstood by the high-ranking state officials.

\section{An assessment of the implementation of performance budgeting in Poland}

The introduction of the performance budget into the system of public finance in Poland finally took place under the Public Finance Act of 27 August 2009. Alongside the previously existing requirement to attach a justification to the budget bill specifying the set of tasks, expenditures, objectives and indicators, the new requirement to describe the state expenditure according to state functions was also introduced. The law obliges the state earmarked funds, executive agencies, and other units of the public finance sector to draft a budget based on the performance structure. Other details concerning budget planning in the performance mode appeared in the regulations on the guidelines to the draft 
of the 2012 budget bill. The correlation of the implementation of performance budgeting in Poland with the Multi-annual Financial Plan of the State is an important aspect.

Pursuant to the above-mentioned Act of 2009, the Finance Minister has issued several decrees, thanks to which the work on the implementation of performance budgeting intensified in the years 2010-2012. First and foremost, twenty-two functions of the state have been outlined, and specific objectives, tasks and sub-tasks have been defined within these functions. The following functions were listed in the state performance-based budget for 2012:

Function 1. Management of the state

Function 2. Internal security and public order

Function 3. Education, upbringing and care

Function 4. State financial management

Function 5. Protection of rights and interests of the Treasury

Function 6. National economic policy

Function 7. Land management, construction and housing

Function 8. Physical culture

Function 9. Culture and national heritage

Function 10. Science and education

Function 11. External security and the inviolability of borders

Function 12. The environment

Function 13. Social security and family support

Function 14. The labour market

Function 15. Foreign policy

Function 16. Civic affairs

Function 17. Balanced regional development of the country

Function 18. Justice

Function 19. Transport infrastructure

Function 20. Health care

Function 21. Agriculture and fisheries policy

Function 22. Strategic planning, and administrative and technical support

A vast catalogue of functions, tasks and sub-tasks, together with their objectives and measures for their implementation, has been drafted for the voivodeship (provincial) offices. The specific character of the role and structure of the voivode budget is evident in this catalogue. Nearly $30 \%$ of the budget 
expenditures are covered by appropriated reserves, with the major part covered fully by the national budget. It's difficult to plan the targets and measure the implementation efficiency of allocated tasks in such circumstances. At the same time, the voivode budget is largely characterized by redistribution, as over $80 \%$ of the total expenditures are covered by appropriated allocations for the local government units. The construction of a system of performance indicators for public tasks is also a difficult challenge, due to the fact that on one hand the voivode enjoys a quite significant degree of freedom in shaping the structure of expenditures within the allotted limit, while on the other hand, many external institutions contribute to the process and they may be bound by different functions and priorities.

Nevertheless, these activities have been important for performance budgeting from the practical point of view and the cohesion of standards. Many practical problems connected with the specific characteristics of individual public tasks and their implementation have emerged in the process of compliance with the standards stipulated in the executive regulations. Many problems related to the allocation of tasks to an individual entity (or entities) have also emerged. This is an important issue, inasmuch as a clear identification of the entity responsible for the implementation of a particular task lies at the heart of performance budgeting. The experience gained during the years 20102012 is supposed to be used in preparing the future budgeting methodology, particularly in drafting the performance indicators for public tasks for specific organizational entities and at specific tiers of public government (Woźniak, Postuła ed. 2012). S. Owsiak (2012, pp. 33-41) outlines important areas of difficulty in connection with the implementation of performance budgeting in Poland:

- the "soft" construction of a large number of indicators and the possibility of manipulating them

- performance budgeting becomes superficial and technocratic

- the overly meticulous nature of some parts that constitute the justification for the budget bill

- information overload for the Parliament, which considerably hinders or even makes a rational decision-making process impossible.

The large amount of budget documents, together with justifications and tables and the necessity to draft documents in both the traditional and performance styles, confirm the above observations. The aforementioned functions of the state are of a different character and vary in importance for national social and economic policy. The actions within these functions are of a vast and difficult-to-measure nature. The "economic policy" function, which has also been defined as "the coordination of economic policy", can be given as 
an example of the problems connected with precisely defining and measuring the tasks within the scope of the function. Additional problems arise from the fact that some of these tasks do not lie within the exclusive competence of the central government, but are implemented by lower tiers or by other, speciallyestablished entities.

Some further steps to perfect the performance budgeting methodology at the central level were taken in 2012 as part of the work on the draft of the performance-based budget for 2013. These mostly concerned the national authorities and central institutions. New regulations were introduced in the Decree of the Minister of Finance of 31 May 2012 on the procedures, modes, and dates for processing materials for the draft of the state budget for 2013. The new regulations slightly modify the principles of defining objectives and indicators by the budget holders, which should strengthen, as is assumed, the link between public expenditures, developmental policy, and the strategic aims and documents of the government. The indicators for effectiveness and efficiency of task implementation are supposed to be more adjusted to the particular actions of the individual budget holders. Similarly to the previous situation, the budget recipients are to play a key role in defining the indicators which apply to their field of action.

The assessment of the actions quoted above and the revision of performance indicators requires a long-term perspective. In the future, a detailed analysis should be undertaken with respect to the excessive formalization of the performance budgeting process. The misuse of public performance indicators (especially at the national scale) may lead to a technocratisation which would obscure the democratic, public, and transparent nature of the budget. It is also important to keep in mind the social and subservient role played by public finances.

\section{Conclusions and proposals de lege ferenda}

- It seems that the higher the absolute value and the level of aggregation of expenditures, the more difficult the rationalization process of expenditures becomes. The fact that performance budgeting has been implemented on a limited scale and with few spectacular successes at the local government tier seems not to auger well for the assessment of future perspectives with respect to performance budgeting. Due to the scope of expenditures, macroeconomic functions, and political perturbations, performance budgeting at the national tier seems even more difficult. 
- The rationalization of expenditures through the performance-based budget will take place only as a result of the correct construction of indicators which, in the experts' opinion, is the most difficult stage in performance budgeting. Authors of indicators are faced with the challenge of the correct aggregation which would result in proper evaluation of the objectives and outcomes of the implemented tasks. The difficulties appear in two aspects: the number of indicators and their values. These two elements will be decisive for the practicality and usefulness of an indicator and its application.

- The use of performance budgeting incurs additional costs. The process is laborious, especially in the phase of construction and interpretation of performance indicators and the audit of the implementation of the objectives and the results reached. The method is also laborious, as it is timeconsuming and requires years of experience. The implementation of a performance-based budget calls for political will and determination, and understanding of the fact that its effects will be visible and financially tangible only in a long-term perspective. The effective implementation of the performance-based budget will require a change in the mentality of civil servants, MPs, and politicians.

- The performance-based budget should, first of all, be vested with the characteristic features of an operational budget. This proposal seems to stand in contrast to the practice so far in Poland. Due to the nature of local government tasks, it is at this tier that the implementation by law of a budget for programmes or selected communal tasks is most reasonable. The balance of expenditures and results would be easier and more effective at this tier than in the case of highly aggregated national tasks. The problem is that the functions, within the framework of the present divisions in governmental administration, make it more difficult to measure and their effectiveness harder to audit. One should assume that many national tasks are immeasurable by nature, and in such a case linking the amount of expenditures to their effectiveness may be pointless or irrational.The profit and loss calculations and the use of public performance indicators are most appropriate in the case of public tasks and services that target individual beneficiaries, while tasks of a strategic and national character are much more difficult to assess and measure.

- One of the major flaws in the implementation of performance budgeting is the lack of appropriate legal provisions and obligations on the local government sector. The legal regulations in this area could refer to selected functions and communal tasks. It is the local government tier, not the central government, that should pioneer performance budgeting on 
a widespread scale. It is also a grave error to neglect the development of a policy of training and persuasion directed towards politicians and local government administrative officials. Presently, the elements of performance budgeting at the local government tier are neither widespread nor standardized.

- Following the example of other countries, Poland has launched the implementation of the performance-based budget, which is categorized as a presentational budget according to the OECD classification. In the coming years, this type of budgeting will be supplemented with information on the effectiveness and efficiency of expenditures and management of entities designated for its implementation. As in many other countries, the requirement to draft a performance-based budget has been introduced at the national level. Such an approach may highlight the enormous complexity, ambiguity and methodological difficulties of the process.

\section{References}

Coombs H.M., Jenkins D.E. (1994), Public Sector Financial Management, Chapman \& Hall, London

European Commission (2009), Public Finances in EMU 2009, European Economy 5/2009, Luxembourg

Hardt Ł, Maarten de Jong (2011), Budżet zadaniowy jako narzędzie poprawy jakości rzadzenia $w$ Polsce (The performance budget as a tool to improve the quality of government in Poland), Sprawne Państwo, Program Ernst \&Young, Warszawa

Jordan M., Hackbart M. (2005), The Goals and Implementation Success of State PerformanceBased Budgeting, Journal of Public Budgeting, Accounting and Financial Management, Vol. 17 (4)

Lubińska T., (ed. 2009), Nowe zarządzanie publiczne - skuteczność i efektywność. Budżet zadaniowy w Polsce (New public management - results and effectiveness. The performance budget in Poland), Difin, Warszawa

Lubińska T. (ed. 2011), Kierunki modernizacji zarzadzania $w$ jednostkach samorzadu terytorialnego (Directions in the modernisation of management of local self-government entites), Difin, Warszawa

Ministry of Finance (2009), Opracowanie dotyczace wizyty przedstawicieli Ministerstwa Finansów na Stowacji (Report on the visit to Slovakia of representatives of the Ministry of Finance), Ministerstwo Finansów RP, 05.10.2012,

http://www.mf.gov.pl/index.php?const=5\&dzial=2062\&wysw=2\&sub=sub2 
Misiąg W. (2005), Mierzenie zadań publicznych jako podstawa planowania budżetowego (Measuremnt of public tasks as the basis of budgetary planning), [in:] Ekonomiczne i prawne problemy racjonalizacji wydatków publicznych", J. Głuchowski, A. Pomorska, J. Szołno-Koguc (ed.), Wydawnictwo UMCS, Lublin

Misiąg W. (2007), Bariery wdrażania budżetowania zadaniowego (Obstacles to the implementation of performance budgeting), [in:] Uwarunkowania i bariery w procesie naprawy finansów publicznych, J. Głuchowski, A. Pomorska, J. Szołno-Koguc (ed.), Wydawnictwo KUL, Lublin

OECD (2005a), Modernising Government: The Way Forward, OECD Publishing, Paris

OECD (2005b), Using Performance Information for Managing and Budgeting:

Challenges, Lessons and Opportunities, GOV/PGC/SBO(2005)3, OECD, Paris

OECD (2005c), Reallocation: The Role of Budget Institutions, OECD Publishing, Paris

OECD (2007), Performance Budgeting in OECD Countries, Paris

Owsiak S. (2012), Węztowe problemy i dylematy zwiazane ze stosowaniem budżetu zadaniowego $w$ Polsce (Thorny problems and dilemmas connected with the application of performance budgeting in Poland), [in:] Budżet zadaniowy metodą racjonalizacji wydatków, B. Woźniak, M. Postuła (ed.), SGH, Warszawa

Raport Budżet Zadaniowy (Report on the Performance Budget) (2007), Tom I, Budżet Zadaniowy na rok 2008, Kancelaria Prezesa Rady Ministrów, Warszawa

Reddick C. (2003), Testing Rival Theories of Budgetary Decision-Making in the US States, Financial Accountability \& Management, Vol. 19 (4)

Robinson M, Last D. (2009), A basic model of performance-based budgeting, Technical Notes and Manuals, International Monetary Found

Rozporządzenie Ministra Finansów z 31.05.2012 r. w sprawie szczegółowego sposobu, trybu i terminów opracowywania materiałów do projektu budżetu państwa na 2013 r., Dz. U. RP z 05.06.2012, poz. 628

Sprawozdanie za rok 2007 z wykonania pilotażu budżetu zadaniowego dla części budżetowych (2007 Report on the execution of the pilot performance budget for certain budgetary categories): Nauka i Szkolnictwo Wyższe (2008), część VI, [w:] Sprawozdanie z wykonania budżetu państwa za okres od 01.01 do 31.122007 r., Omówienie, Rada Ministrów, Warszawa

Ustawa o Finansach Publicznych (Public Finance Act) z 30.06.2005, Dz. U. Nr 249, poz. 2104

Ustawa o Finansach Publicznych (Public Finance Act) z 27.08.2009, Dz. U. Nr 157, poz. 1240

Ustawa Budżetowa na rok 2012 (The Budgetary Act for 2012) (2011), Uzasadnienie tom II, tom III, Omówienie, Wydatki Państwa w Układzie Zadaniowym, Warszawa

Woźniak B., Postuła M. (ed. 2012), Budżet zadaniowy metoda racjonalizacji wydatków (Performance budget as a metod for rationalizing expenditures), SGH, Warszawa 
Young R.D. (2003), Performance-based budget systems, Public Policy and Practice, January 2003, USC Institute for Public Service and Policy Research, University of South Carolina

\section{Streszczenie}

\section{OCENA IMPLEMENTACJI BUDŻETOWANIA ZADANIOWEGO W POLSCE NA TLE DOŚWIADCZEŃ INNYCH PAŃSTW}

Po ostatnim globalnym kryzysie finansowym, wydatkowanie środków publicznych ma miejsce w warunkach coraz większych ograniczeń budżetowych. Władze publiczne poszukuja więc rozwiąań sprzyjajacych efektywnemu, skutecznemu i przejrzystemu dokonywaniu wydatków, zarówno na szczeblu państwa jak i samorząu terytorialnego. Jednym z takich narzędzi jest budżet zadaniowy, który nie jest jednak rozwiazaniem tanim i łatwym w praktycznym wykorzystaniu. Celem rozważań jest ocena implementacji budżetowania zadaniowego $w$ Polsce oraz sformułowanie propozycji de lege ferenda. W ocenie tej wykorzystano również wybrane aspekty $i$ wnioski ptynace $z$ doświadczeń innych państw. Główna teza postawiona w podsumowaniu jest wskazanie, $i \dot{z}$ niezbyt stusznie $i$ trafnie, wdrażanie budżetu zadaniowego ma miejsce $w$ wielu państwach, w tym również $w$ Polsce, najpierw na szczeblu państwa, a nie samorząu terytorialnego. 